\title{
Involvement of the oestrogenic receptors in superior mesenteric ganglion on the ovarian steroidogenesis in rat
}

\author{
Adriana Vega Orozco, Cristina Daneri, Gabriel Anesetti ${ }^{1}$, Ricardo Cabrera ${ }^{2,3}$, Zulema Sosa and \\ Ana M Rastrilla \\ Laboratorio de Biología de la Reproducción (LABIR), Facultad de Química, Bioquímica y Farmacia, Universidad \\ Nacional de San Luis, San Luis, Argentina, 'D Departamento de Histología y Embriología, Facultad de Medicina, \\ Universidad de la República, General Flores 2125, CP 11800 Montevideo, Uruguay, ${ }^{2}$ Instituto de Ciencias \\ Biomédicas, Facultad de Ciencias Médicas, Universidad de Mendoza, Mendoza, Argentina and ${ }^{3}$ Instituto de \\ Medicina y Biología Experimental de Cuyo (IMBECU)-Consejo National de Investigaciones Científicas y \\ Technológicas (CONICET), Mendoza, Argentina
}

Correspondence should be addressed to A Vega Orozco; Email: adriana.vega@um.edu.ar, Z Sosa; Email: zsosa@unsl.edu.ar

\begin{abstract}
Oestradiol $\left(E_{2}\right)$ is a key hormone in the regulation of reproductive processes. The aims of this work were a) to examine the distributions of oestrogen receptor $\alpha(E R \alpha)$ and $E R \beta$ in the neurons of the superior mesenteric ganglion (SMG) in the oestrus stage by immunohistochemistry, b) to demonstrate whether $E_{2}$ in the SMG modifies progesterone $\left(P_{4}\right)$, androstenedione $\left(A_{2}\right)$ and nitrite release in the ovarian compartment on oestrus day and $c$ ) to demonstrate whether $E_{2}$ in the ganglion modifies the activity and gene expression in the

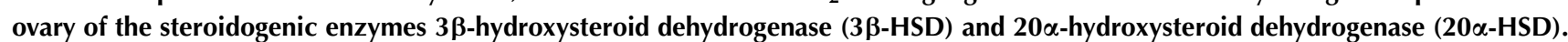
The ex vivo SMG-ovarian nervous plexus-ovary system was used. $E_{2}$, tamoxifen (Txf) and $E_{2}$ plus Txf were added in the ganglion to measure ovarian $P_{4}$ release, while $E_{2}$ alone was added to measure ovarian $A_{2}$ and nitrites release. Immunohistochemistry revealed cytoplasmic ER $\alpha$ immunoreactivity only in the neural somas in the SMG. $E_{2}$ increased ovarian $P_{4}$ and $A_{2}$ release at 15, 30 and 60 min but decreased nitrites. The activity and gene expression of $3 \beta-H S D$ increased, while the activity and gene expression of $20 \alpha-H S D$ did not show changes with respect to the control. Txf in the ganglion diminished $P_{4}$ release only at 60 min. $E_{2}$ plus Txf in the ganglion reverted the effect of $E_{2}$ alone and the inhibitory effect of Txf. The results of this study demonstrate that ER $\alpha$ activation in the SMG has an impact on ovarian steroidogenesis in rats, thus providing evidence for the critical role of peripheral system neurons in the control of ovarian functions under normal and pathological conditions.

Reproduction (2012) 143 183-193
\end{abstract}

\section{Introduction}

There is ample evidence demonstrating a functional interaction between the peripheral nervous system and the reproductive system (Sosa et al. 2000, 2004, Casais et al. 2006). The ovary receives sympathetic innervation from the prevertebral ganglia by two routes: the ovarian nervous plexus (ONP) and the superior ovarian nerve (SON). The ONP fibres originate mostly in the neurons of the superior mesenteric ganglion (SMG; Baljet \& Drukker 1979, Klein \& Burden 1988a) and accompany the ovary artery in its entrance to the hilum. This pathway not only innervates the blood vessels but also the veins that form a net around the theca cells (Lawrence \& Burden 1980). The SMG is included in the sympathetic prevertebral chain; it is constituted by principal neurons and interneurons (Eränkö 1978, Prud'Homme et al. 1999) and it has a profuse capillary plexus that constitutes a microcirculation among the different ganglionic structures. The sympathetic ganglia possess a great variety of specific receptors and neurotransmitters, such as catecholamines (Klein \& Burden 1988a) and neuropeptides (Dalsgaard et al. 1982). These ganglia are active points of concurrency for hormone signals, as revealed by the metabolic changes induced by steroids, as well as by the existence of putative receptors for some hormones such as oestradiol ( $\mathrm{E}_{2}$; Cardinali et al. 1983).

Oestrogens are important for the development of sexual phenotype and differentiation of the central nervous system (CNS). They play crucial roles in the development of the pituitary gonadal axis, ovarian folliculogenesis, ovulation and implantation, thereby acting on peripheral organs and sympathetic neurons associated with functions related to reproduction (Anesetti et al. 2009). Zoubina \& Smith (2003) demonstrated that a small number of uterine-projecting neurons located in the SMG and other sympathetic ganglia expressed oestrogen receptors (ERs). Their 
actions are mediated through two distinct receptors, ER $\alpha$ and $E R \beta$, which bind to specific DNA sequences regulating transcription. $E R \alpha$ is also localised in the plasma membrane and may help to elucidate the mechanisms through which rapid, 'non-genomic' oestrogen signalling occurs (Deecher et al. 2003, Doolan \& Harvey 2003, Wang et al. 2005). ERs are regulated in a tissue- and/or cell-type specific manner and $E_{2}$ itself seems to play an important role in this regulation (Weihua et al. 2003).

A simple dose of $E_{2}$ valerate can modify the levels of expression of the enzyme tyrosine hydroxylase (TH), the rate-limiting enzyme in catecholamine biosynthesis, which induces changes in the nervous sympathetic activity in the ovary of mammals (Shinohara et al. 1998, Lara et al. 2000), provoking alterations in the follicular growth that lead to the development of polycystic ovaries (Lara et al. 2002, Rosa et al. 2003).

This enzyme, together with dopamine $\beta$-hydroxylase, which also participates in the biosynthesis pathway of catecholamines, colocalises with immunoreactive neuropeptides and choline acetyltransferase, the enzyme for the acetylcholine synthesis pathway (LarsGösta et al. 1997).

Indirect immunofluorescence studies have demonstrated the presence of the isoenzyme neuronal nitric oxide synthase (nNOS) in the SMG (Quinson et al. 2001). Berman et al. (1998) have demonstrated that $\mathrm{ER} \alpha$ is predominantly expressed by nitric oxide synthase (NOS)-positive in parasympathetic pelvic ganglion neurons. There is evidence that $\mathrm{NO}$ decreases the steroidogenesis in different experimental schemes (Olson et al. 1996, Snyder et al. 1996), causing an inhibition of the enzymatic activities and gene expression of steroid synthesis-limiting enzymes such as $3 \beta$-hydroxysteroid dehydrogenase $(3 \beta$-HSD) in bovine luteal cells (Rekawiecki et al. 2005). Vega Orozco et al. (2006) have demonstrated in an ex vivo system that the ganglionic cholinergic stimulus modifies the ovarian steroids and $\mathrm{NO}$ release in the oestrus stage.

With these antecedents in mind and considering the neural influence from the SMG through the ONP on ovarian steroidogenesis, the aims of this work were a) to examine the distributions of $E R \alpha$ and $E R \beta$ in neurons of the SMG during the oestrus (E) stage by immunohistochemistry, b) to demonstrate whether $E_{2}$ in the SMG modifies progesterone $\left(\mathrm{P}_{4}\right)$, androstenedione $\left(\mathrm{A}_{2}\right)$ and nitrite $(\mathrm{NO})$ release in the ovarian compartment on oestrus day and $\mathrm{c}$ ) to demonstrate whether $\mathrm{E}_{2}$ in the ganglion modifies the activity and gene expression in the ovary of the steroidogenic enzymes $3 \beta-\mathrm{HSD}$ and $20 \alpha-\mathrm{HSD}$.

\section{Results}

\section{Localisation of ERs in the SMG on oestrus day by immunohistochemistry}

The histological study of the SMG showed a thin capsule of connective tissue and the parenchyma exhibited several neuronal profiles (Fig. 1A). ER $\alpha$ immunoreactivity was observed in most neuronal somas of the SMG, and its pattern was cytoplasmic and heterogeneous (Fig. 1B). Uterine control sections displayed the classical nuclear localisation of this receptor. ER $\beta$ immunoreactivity was not observed in neuronal somas (Fig. 1C). Figure 1D shows a high magnification of Fig. 1C $(40 \times)$. Rat ovary was used as the positive control for ER $\beta$ (Fig. 1D'). No positive structures or cells were observed in the SMG sections when the primary antiserum was not added (negative control; Fig. 1D").
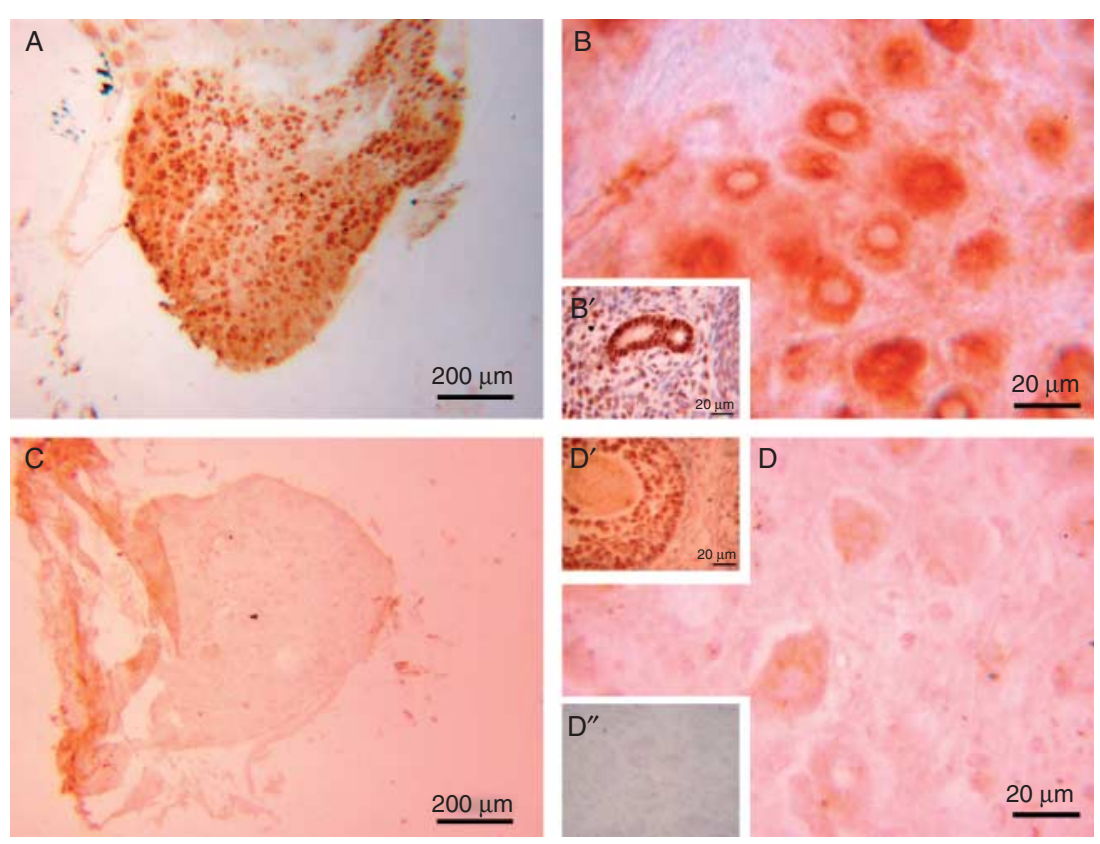

Figure 1 (A-D) (A) Low magnification of the SMG showing that almost all neurons displayed immunoreactivity for $\mathrm{ER} \alpha(4 \times)$. (B) High magnification of $\mathrm{A}(40 \times)$. Note the extensive immunoreactivity restricted to cytoplasm. No nuclear signal was detected. $\left(\mathrm{BB}^{\prime}\right)$ Inset of positive control for $E R \alpha$ in rat uterus showing intense signal in glandular and stromal endometrial cells $(40 \times)$. (C) Low magnification of the SMG showing absence of $E R \beta$ reactivity $(4 \times)$. (D) High magnification of $C(40 \times)$. $\left(D^{\prime}\right)$ Inset of positive control for $E R \beta$ in rat ovary $(40 \times)$. $\left(D^{\prime \prime}\right)$ Inset of negative control for ER $\beta$ in rat SMG. 


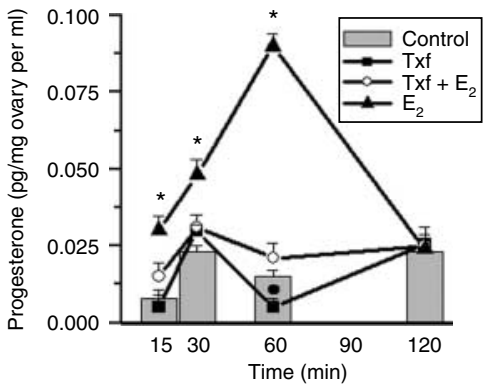

Figure 2 Effect of oestradiol $\left(E_{2}\right)$ and tamoxifen $(T x f)$ in the superior mesenteric ganglion on the ovarian progesterone release in the superior mesenteric ganglion-ovarian nervous plexus-ovary system removed from oestrus day rat. The systems were incubated in a Krebs-Ringer buffer, plus ascorbic acid $\left(0.1 \mathrm{mg} / \mathrm{ml}\right.$ in Krebs-Ringer) solution, at $37^{\circ} \mathrm{C}$ in an atmosphere of $95 \% \mathrm{O}_{2}$ to $5 \% \mathrm{CO}_{2}$ for $120 \mathrm{~min}$ without (control) and with the addition of $E_{2}\left(10^{-6} \mathrm{~mol} / \mathrm{l}\right)$, $\operatorname{Txf}\left(10^{-6} \mathrm{~mol} / \mathrm{l}\right)$ and $E_{2}$ plus Txf in the ganglion compartment (experimental group). $\mathrm{E}_{2}, \mathrm{E}_{2}$ valerate. Values are the mean \pm s.E.M. of six animals per experimental group. Columns with ${ }^{*}$ and ${ }^{\bullet}$ indicate statistical significance of $* P<0.001$ and $\bullet<<0.05$, respectively, compared with the control group (Student's t-test, ANOVA, Duncan's test).

\section{Ganglionic effect of $E_{2}$ and tamoxifen on ovarian $P_{4}$ release on oestrus}

To evaluate whether the presence of $\mathrm{E}_{2}$ and its antagonist in the ganglion compartment modulated the release of ovarian $\mathrm{P}_{4}$ in the ex vivo system and considering that this steroid has proved to be the most sensitive steroid to neural influence in in vitro studies, $\mathrm{E}_{2}\left(10^{-6} \mathrm{~mol} / \mathrm{l}\right)$, tamoxifen (Txf) only and $E_{2}$ plus Txf were added in the SMG. Txf was used since this antagonist is specific for $\mathrm{ER} \alpha$ (Sun et al. 2010).

$\mathrm{E}_{2}$ in the ganglion increased ovarian $\mathrm{P}_{4}$ release at $15 \mathrm{~min}(0.008 \pm 0.001$ vs $0.03 \pm 0.001), 30 \mathrm{~min}(0.023$ \pm 0.002 vs $0.048 \pm 0.001)$ and $60 \mathrm{~min}(0.015 \pm 0.006$ vs $\left.0.09 \pm 0.004 ;{ }^{*} P<0.001\right)$, whereas Txf alone decreased $\mathrm{P}_{4}$ release only at $60 \mathrm{~min}(0.015 \pm 0.002$ vs $0.005 \pm 0.001 ; \cdot P<0.05)$ with respect to the control group. The addition of $E_{2}\left(10^{-6} \mathrm{~mol} / \mathrm{l}\right)$ plus Txf in the ganglion did not show changes in ovarian $\mathrm{P}_{4}$ release in comparison with the control group (Fig. 2).

\section{Effect of $E_{2}$ in the ganglion on the enzymatic activity and gene expression of the ovarian $3 \beta-H S D$ and $20 \alpha-H S D$ steroidogenic enzymes on oestrus}

To evaluate whether the addition of $E_{2}$ in the mesenteric ganglion modified the activity and gene expression of the $\mathrm{P}_{4}$ synthesis enzymes in the oestrus stage, the ovaries of the system were obtained after 120 min of incubation.

$\mathrm{P}_{4}$ in the ganglion increased the ovarian enzymatic activity and gene expression of $3 \beta-\mathrm{HSD}$ at $120 \mathrm{~min}$ of incubation $\left({ }^{*} P<0.001\right.$; Figs 3 a and $\left.4 \mathrm{a}\right)$, whereas the activity and gene expression of $20 \alpha-\mathrm{HSD}$ did not show significant changes at $120 \mathrm{~min}$ with respect to the control (Figs $3 \mathrm{~b}$ and $4 \mathrm{~b}$ ).

\section{Effect of $E_{2}$ in ganglion on ovarian $A_{2}$ release on oestrus}

Considering that $A_{2}$ is synthesised by the ovarian interstitial cells and that ONP innervated these structures, $A_{2}$ release in the ovarian compartment by stimulation with $\mathrm{E}_{2}$ at the ganglionic level was assessed.

$E_{2}$ in the ganglion increased the release of $A_{2}$ in the ovarian compartment at $15 \mathrm{~min}(0.024 \pm 0.01$ vs $0.354 \pm 0.01), 30 \mathrm{~min}(0.595 \pm 0.01$ vs $0.92 \pm 0.01$; $* P<0.001)$ and $60 \mathrm{~min}(0.42 \pm 0.01$ vs $0.98 \pm 0.01$; $* P<0.001$; Fig. 5).

\section{Effect of $E_{2}$ in the ganglion on ovarian nitrite release on oestrus}

The modulation of the release of nitrites by neural stimulus and their importance in the reproductive function has been demonstrated in our research group; therefore, we attempted to determine whether the addition of $E_{2}$ in the ganglion compartment modifies nitrite release on the ovarian compartment on oestrus day.

$E_{2}$ caused a significant decrease in nitrite release at all incubation times in comparison with the control group $\left({ }^{*} P<0.001\right.$; Fig. 6$)$.

\section{Discussion}

Given the importance of the neural regulation from the peripheral nervous system on ovarian physiology (Sosa et al. 2000, Casais et al. 2006, Vega Orozco et al. 2010) and taking into account that $E_{2}$ acts on peripheral organs and on the plasticity of sympathetic neurons associated with reproduction (Anesetti et al. 2009), the general aim of this work was to examine the distributions of $E R \alpha$ and ER $\beta$ in neurons of the SMG and to evaluate the importance of these receptors in ovarian steroidogenesis and their possible relation with $\mathrm{NO}$ release.

In this work, ER $\alpha$ was typified by immunohistochemistry in the SMG, but ER $\beta$ was not detected probably due to the fact that receptors of this type have been
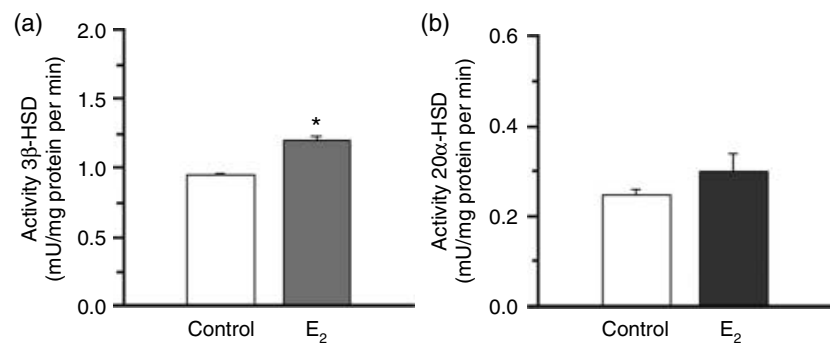

Figure 3 Effect of oestradiol $\left(E_{2}\right)$ in the ganglion compartment on the enzymatic activity of $3 \beta-\mathrm{HSD}$ (a) and $20 \alpha-\mathrm{HSD}$ (b) in ovaries extracted from the superior mesenteric ganglion-ovarian nervous plexus-ovary system with and without the addition of $\mathrm{E}_{2}\left(10^{-6} \mathrm{~mol} / \mathrm{l}\right)$ in the mesenteric ganglion at $120 \mathrm{~min}$ of incubation on oestrus day. $E_{2}, E_{2}$ valerate. Values are the mean \pm s.E.M. of six animals in two experiments. Columns with *indicate statistical significance of $* P<0.001$ compared with the control group (Student's $t$-test; ANOVA, Duncan's test). 

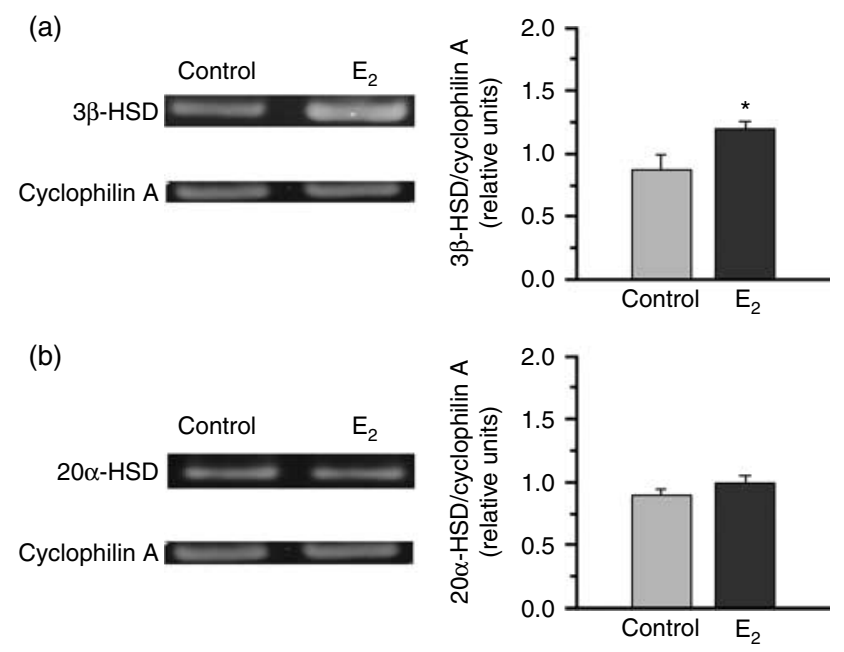

Figure 4 Ganglionic effect of oestradiol on mRNA abundances of enzymes $3 \beta-H S D$ (a) and $20 \alpha-H S D$ (b) obtained from rat ovary previously incubated in the superior mesenteric ganglion-ovarian nervous plexus-ovary system on oestrus day. Measurement by RT-PCR of the expression of $3 \beta-\mathrm{HSD}$ and cyclophilin A. Ethidium bromide fluorescence photograph of the gel electrophoresis of the amplification products. Expression of $3 \beta-\mathrm{HSD}$ relative to cyclophilin A. The gel photographs were quantified using Image J (NIH, Bethesda, MA, USA) and expressed as arbitrary units. Results are expressed as the mean \pm S.E.M. $(n=3) .{ }^{*} P<0.001$.

fundamentally found in prepubertal (Shinohara et al. 2000, Anesetti et al. 2009) and adult rats in other cycle stages (Zoubina \& Smith 2002). The results obtained in this work differ from those reported by Zoubina \& Smith (2002), who found, in a different experimental scheme, that the vast majority of sympathetic neurons express ER $\beta$ immunoreactive protein, whereas a smaller, presumably overlapping subset expresses the ER $\alpha$. Papka et al. (2001) found that both receptors could potentially be affected by changes in endogenous oestrogen levels, which could explain why ER $\beta$ was not found in our study. Our findings showed that in SMG neurons, ER $\alpha$ was mainly distributed uniformly throughout the neuronal cytoplasm on oestrus day, but it was not observed in satellite or Schwann cells, in agreement with the findings reported by Anesetti et al. (2009) on lumbar paravertebral and prevertebral sympathetic ganglia in prepubertal animals. Moreover, immunocytochemical studies have demonstrated an extranuclear localisation for the ERs in neurons of rat brain (Blaustein 1992).

It is important to emphasise that in the case of neurons associated with the ovary, the studies are scanty and basically linked to long-term effects on the physiology of the organ, when oestrogens are applied in early stages of the development (Shinohara et al. 1998, 2000, Lara et al. 2000, Koszykowska et al. 2011). The functions of ERs in sympathetic ganglia are related to the protection of the neurons against damage and the regulation of the growth of the neuronal prolongations (Sohrabji et al. 1994a, 1994b). Both ERs have similar affinities for binding $E_{2}$
(Mosselman etal. 1996, Kuiper et al. 1997) and could exert their effect through different signalling paths. However, the tissue distribution and level of expression of $E R \alpha$ and $E R \beta$ vary in sympathetic ganglia (Zoubina \& Smith 2002).

It has been demonstrated that besides the well-studied transcriptional effects of $E_{2}$, there are rapid effects, i.e. occurring within seconds or minutes after the addition of $\mathrm{E}_{2}$ (Song et al. 2005, Song \& Santen 2006, Warner \& Gustafsson 2006). These rapid effects are probably produced through non-genomic mechanisms, as has been observed in several tissues (Heldring et al. 2007). However, there is no agreement yet as to the participation of the classical oestrogenic receptors (Levin 2001, Deecher et al. 2003, Razandi et al. 2004) or whether there is a distinct membrane-associated receptor, such as GPR30 (Doolan \& Harvey 2003, Dun et al. 2009).

It has been reported that oestrogen rapidly (between 5 and $15 \mathrm{~min}$ ) increases the activity of mitogen-activated protein kinase, which persists for at least $2 \mathrm{~h}$ (Singh et al. 1999). In concordance with the above results, the addition of $E_{2}$ in the $S M G$ produces a rapid increase in ovarian $\mathrm{P}_{4}$ and $\mathrm{A}_{2}$ release at $15 \mathrm{~min}$, reaching a maximum at $60 \mathrm{~min}$ and a decrease at $120 \mathrm{~min}$, in agreement with Singh et al. (1999). This effect observed on ovarian $\mathrm{P}_{4}$ release might be due to the classical ER $\alpha$ found in the SMG, considering that by immunohistochemistry the ER $\beta$ was not observed in the ganglion, or else, to some other type of oestrogenic receptor, probably GPR30, which has been found at the sympathetic ganglionic level (Dun et al. 2009), might be involved in the rapid responses obtained on the release of ovarian $\mathrm{P}_{4}$.

The effect of $E_{2}$ stimulus in the ganglion on ovarian $P_{4}$ and $A_{2}$ released might be accounted for by an increase in cAMP levels in neurons that constitute the SMG and the consequent increase in ovarian noradrenaline (NA) as

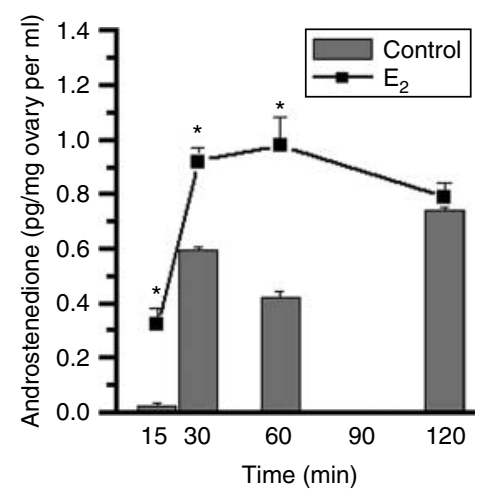

Figure 5 Effect of oestradiol $\left(E_{2}\right)$ on ovarian androstenedione release in the superior mesenteric ganglion-ovarian nervous plexus-ovary system removed from rats on oestrus day. The systems were incubated in KrebsRinger buffer, plus ascorbic acid $(0.1 \mathrm{mg} / \mathrm{ml}$ in Krebs-Ringer) solution, at $37^{\circ} \mathrm{C}$ in an atmosphere of $95 \% \mathrm{O}_{2}$ to $5 \% \mathrm{CO}_{2}$ for 120 min without (control) and with the addition of $\mathrm{E}_{2}\left(10^{-6} \mathrm{~mol} / \mathrm{l}\right)$ to the ganglion compartment (experimental group). $E_{2}, E_{2}$ valerate. Each bar represents the mean \pm S.E.M. of six animals per experimental group. ${ }^{*} P<0.001$ compared with the control group (Student's $t$-test; ANOVA, Duncan's test). 


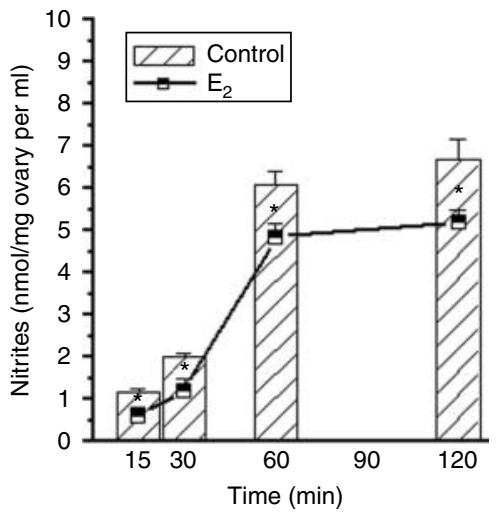

Figure 6 Effect of oestradiol $\left(E_{2}\right)$ in the ganglion compartment on nitric oxide $(\mathrm{NO})$ release in the incubation liquid of the ovarian compartment in the superior mesenteric ganglion-ovarian nervous plexus-ovary system of rats on oestrus day. The system was incubated in KrebsRinger buffer, plus ascorbic acid $(0.1 \mathrm{mg} / \mathrm{ml}$ in Krebs-Ringer) solution, at $37{ }^{\circ} \mathrm{C}$ in an atmosphere of $95 \% \mathrm{O}_{2}$ to $5 \% \mathrm{CO}_{2}$ for $120 \mathrm{~min}$ without (control) and with the addition of $\mathrm{E}_{2}\left(10^{-6} \mathrm{~mol} / \mathrm{l}\right)$ to the ganglion compartments (experimental group). $\mathrm{E}_{2}, \mathrm{E}_{2}$ valerate. Values are the mean \pm S.E.M. of six animals per experimental group. Columns with * indicate statistical significance of $* P<0.001$ compared with the control group (Student's $t$-test; ANOVA, Duncan's test).

stated by Lara et al. (2002), with an increased capacity of the ovarian nerve terminals to incorporate and release NA. The effects of catecholamines in the ovary have been demonstrated in other experimental schemes (Aguado \& Ojeda 1984, Barria et al. 1993).

Sosa et al. (2004) demonstrated in an ex vivo system that the cholinergic stimulus in the coeliac ganglion caused changes in $\mathrm{NA}$ and $\mathrm{P}_{4}$ release at the ovarian level, according to the stage of the oestrous cycle, and this constitutes one of the factors governing the secretory activity of the ovarian steroids (Sosa et al. 2004). Recent studies using the SMG-ONP-ovary system have determined an increase in NA release in the ovarian compartment on oestrus day by cholinergic ganglionic stimulus (A Vega Orozco, C Daneri, D Bronzi, Z Sosa, AM Rastrilla, unpublished observations, 2010).

It has been demonstrated that the neuronal population in mesenteric ganglia is very heterogeneous, with numerous peptides and neurotransmitters. It has been shown in our research group that ganglionic stimulation in this ex vivo system releases not only catecholamines but also gonadotropin-releasing hormone $(\mathrm{GnRH})$ and NO (A Vega Orozco, C Daneri, D Bronzi, Z Sosa, AM Rastrilla, unpublished observations, 2010). Garraza et al. (2004) demonstrated that the effect of other neurotransmitters such as substance $\mathrm{P}$ (SP) and neuropeptide Y (NPY) depends on the oestric cycle and that they can exert effects on the postganglionic terminal that reaches the ovary. These authors demonstrated that the addition of $\mathrm{NA}$ alone in hemi-ovaries incubations increases $\mathrm{P}_{4}$ release while the addition of NPY, SP and vasoactive intestinal peptide (VIP) alone and together with NA generally decreases $\mathrm{P}_{4}$ release at short times and increases it at long times. In addition, Miyamoto et al. (1993) reported that the addition of NPY, SPand VIP in cultures of luteal cells at short times and in the absence of luteinising hormone (LH) decreases the release of $\mathrm{P}_{4}$, although using a different experimental scheme. In our system, which is free of humoral influences, there was an increase in $\mathrm{P}_{4}$ by oestrogenic stimulation at ganglionic level.

With regard to the enzymes involved in the synthesis and degradation of $\mathrm{P}_{4}$, the addition of $\mathrm{E}_{2}$ in the ganglion increased the enzymatic activity and gene expression of $3 \beta$-HSD but not $20 \alpha-$ HSD in the ovary at 120 min of incubation in relation to the control. This result is surprising since there are no reports of enzymatic activity modulation at such short times. Variations in luteal cell cultures occurring at $36 \mathrm{~h}$ without neural influence and without the paracrine relations present in our ex vivo system have been reported (Tellería et al. 1995, Stocco \& Deis 1996). It is important to note that although in this case $E_{2}$ in the ganglion has a short time effect $(15 \mathrm{~min})$, Singh et al. (1999) report that $E_{2}$ acts between 5 and $120 \mathrm{~min}$. For this reason, the enzymatic activity and gene expression of ovarian $3 \beta-$ HSD were measured at 120 min of incubation.

Considering that NA released at the ovarian level by the oestrogenic ganglionic stimulus might be responsible for the increase in ovarian $\mathrm{P}_{4}$, the findings of this study are in agreement with postulations by Hsueh et al. (1984) and Miszkiel et al. (1999) that NA stimulates the activity of $3 \beta-\mathrm{HSD}$. At the same time, $\mathrm{P}_{4}$ produced by NA stimulus reduces the activity of monoaminooxidase (MAO) and catechol-O-methyl-transferase, the enzymes primarily responsible for the degradation of catecholamines (Mannisto \& Kaakkola 1999, Eisenhofer et al. 2004). Thus, in this way, $\mathrm{P}_{4}$ prolongs the half-life of $\mathrm{NA}$ and the duration of its stimulatory influence on $\mathrm{P}_{4}$ synthesis.

Also, taking into account that Kotwica et al. (2004) and Rekawiecki et al. (2008) have postulated the autoregulation of $\mathrm{P}_{4}$ synthesis in the corpus luteum, which affects the transcription of the genes encoding steroidogenic enzymes, it can be assumed that the values of $\mathrm{P}_{4}$ can be due to the increase in the activity and gene expression of $3 \beta-\mathrm{HSD}$ caused by the same $\mathrm{P}_{4}$ released throughout time. The accumulation of $\mathrm{P}_{4}$ in ovarian steroidogenic cells is also influenced by the participation of the enzyme $20 \alpha-\mathrm{HSD}$, a $\mathrm{P}_{4}$ degradation enzyme, which has been determined, cloned and sequenced in the corpus luteum of rats (Mao et al. 1997). In our case, this enzyme did not suffer variations at the studied times.

When the ERs antagonist was added, Txf alone in the ganglion inhibited ovarian $\mathrm{P}_{4}$ release only at $60 \mathrm{~min}$. Possibly, the effect of Txf occurs at the ganglionic level. In fact, Paech et al. (1997) and Kuiper et al. (1999) have demonstrated that the effect of Txf varies with the type of tissue and has action mechanisms that are different compared with traditional receptors (Paige et al. 1999, Zou et al. 1999). It is possible that, due to the $E_{2}$ level at this stage, the levels of the ER $\beta$ in the ganglion are too low 
to be detected by immunohistochemistry. Both receptors are probably co-expressed at the ganglionic level, where $E R \beta$ antagonises the actions that depend on ER $\alpha$ as has been observed in other studies (Paech et al. 1997). Thus, the addition of an antagonist as Txf in the ganglion caused an inhibition of ovarian $\mathrm{P}_{4}$ release at $60 \mathrm{~min}$, an opposite to that of $E_{2}$ alone at the ganglionic level. The effects of $E_{2}$ and $\mathrm{Txf}$ alone were reverted by the addition of $\mathrm{E}_{2}$ plus $\mathrm{Txf}$, taking the $\mathrm{P}_{4}$ levels to control values.

On the other hand, we postulate that the inhibitory effect of Txf alone in the ganglion might be through the $E R \beta$. Webb et al. (1995) have demonstrated that antioestrogens such as Txf act as agonists of an alternative pathway (AP-1) to the classical ERs one, which is more potent in the presence of ER $\beta$. Thus, it has been demonstrated that the ER $\beta$ potentially increases the transcription dependent on this alternative way in the presence of anti-oestrogens, but it is not activated in the presence of oestrogens, which might explain an inhibitory effect of Txf through this receptor that apparently acts as a repressor (Navarro Despaigne 2001). Thus, this effect is reverted by the addition of $E_{2}$ plus Txf at the ganglionic level. This issue will be the subject of future research.

It must be noted that in previous work, we demonstrated in the same SMG-ONP-ovary system that, besides catecholamines, other neurotransmitters such as NO may be released from the ONP by way of the ganglionic stimulus (Vega Orozco et al. 2010). Evidence has been reported that supports the involvement of $\mathrm{NO}$ in ovarian physiology (Fridén et al. 2000, Motta et al. 2001). In addition, it has been demonstrated that oestrogen up-regulates neuronal NOS expression through ER $\alpha$ in parasympathetic pelvic ganglion neurons (Berman et al. 1998). However, other investigators have shown that the various ERs on the cell surface are coupled to constitutive NOS-derived NO release (Stefano et al. 2003).

Our research group has demonstrated that the cholinergic agent in the coeliac ganglion stimulates NO release through NOS in prepubertal rat ovaries (Delgado et al. 2004). Studies with antagonists of the neuronal and inducible NO enzyme, both at the ganglionic and ovarian levels, showed that NO can reach the ovary by neural ways or be synthesised at the ovarian level (Delgado et al. 2004, Casais et al. 2006). In addition, Vega Orozco et al. $(2006,2010)$ have demonstrated that NO is involved in the formation and maintenance of the corpus luteum during the oestrous cycle through the ONP pathway.

Considering the above antecedents, it was decided to evaluate whether NO release is modified at the ovarian level by ganglionic oestrogenic stimulus in the ex vivo system and whether its presence is involved in ovarian steroidogenesis. Nitrites were found to decrease in the ovary compartment, which might be attributed to the direct action of oestrogen on the activity of one or more isoforms of the NO synthesis enzyme present in the ganglion, as was also observed by other authors (Stefano et al. 2003).
On the other hand, it is important to note that $\mathrm{NO}$ has been reported to decrease $\mathrm{P}_{4}$ and $\mathrm{A}_{2}$ release in in vitro cellular cultures (Olson et al. 1996, Dunnam et al. 1999, Fridén et al. 2000). Motta et al. (2001) have shown in rat that endogenous $\mathrm{NO}$ increased the production of glutathione and $\mathrm{P}_{4}$ in corpora lutea in the middle stage of development. This result shows a dual, protective or pro-oxidising effect according to the stage of the oestrous cycle during which the tissue was obtained (Dong et al. 1999). Therefore, NO may be a luteolytic and/or luteotrophic factor on the corpus luteum, depending on the stage of the oestrous cycle (Olson et al. 1996, Fridén et al. 2000, Motta et al. 2001). In addition, Yamamoto et al. (1993) have demonstrated that NO might be involved in the modulation of the output and synthesis of NA, which is in agreement with the postulation that NA might be responsible for $\mathrm{P}_{4}$ increase.

$E_{2}$ action in the ganglion observed in the present work probably favours the observed ovarian $\mathrm{P}_{4}$ increase, having a trophic effect on the corpus luteum. On the basis of the results we obtained, we can propose that oestrogenic stimulus on the SMG would act in favour of the events that lead to the ovulation and later formation of the corpus luteum.

There is ample evidence suggesting that the sympathetic nervous system is involved in pathologies associated with the reproductive system. The role of oestrogen at the ganglionic level on ovarian steroidogenesis remains unclear and controversial. Anesetti et al. (2009) demonstrated that elevated levels of exogenous oestrogen during the prepubertal period in postganglionic sympathetic neurons increased sympathetic coeliac neuronal size and modified the expression of $p^{75 N T R}$ (p75 neurotrophin receptor), inducing a significant increase in catecholaminergic innervation of the ovary.

Polycystic ovary syndrome (PCOS) is associated with an abnormal activation of the sympathetic nervous system, showing an impaired metabolism of NA in adolescents suffering from this disease (Garcia-Rudaz et al. 1998).

The results of this study demonstrate that ER $\alpha$ activation in the SMG has an impact on ovarian steroidogenesis in rats at the ovarian level, thus providing evidence for the critical role of peripheral system neurons in the control of ovarian functions under normal and possibly under pathological conditions such as PCOS and ovarian cancer.

This work is expected to contribute new evidence for the clinical importance of these receptors in the therapy and prevention of ovarian pathology.

\section{Materials and Methods}

\section{Animals}

Virgin Holtzman strain adult female rats on oestrus (E) day weighing $250 \mathrm{~g}$ were used in all the experiments. The rats were kept in a light- (lights on from 0700 to $1900 \mathrm{~h}$ ) and 
temperature-controlled room $\left(24 \pm 2{ }^{\circ} \mathrm{C}\right)$. Animals had free access to food (Cargill, SACl, Saladillo, Buenos Aires, Argentina) and tap water was available ad libitum. Vaginal smears were taken daily, and only the rats exhibiting at least two 4-day consecutive oestrous cycles were used. Groups of six animals were used for each group utilised in the experimental procedure. The experiments were performed per duplicate according to the procedures approved in the UFAW Handbook on the Care and Management of Laboratory Animals (Poole 1999). The experimental protocol was approved by the University of San Luis Animal Care and Use Committee (number protocol: B17/04, ordinance CD 006/02).

\section{Chemicals}

The compounds $E_{2}$ valerate $\left(E_{2}\right)$, Txf, ascorbic acid, BSA fraction $\mathrm{V}$, sulphanilamide and $\mathrm{N}$-(1-naphthyl)ethylenediamine were purchased from Sigma-Aldrich Co. Other reagents and chemicals were of analytical grade. 1,2,6,7-[ $\left.{ }^{3} \mathrm{H}\right]-\mathrm{P}_{4}$ (107.0 Ci/mmol), 1,2,6,7- $\left[{ }^{3} \mathrm{H}\right]$-androst 4-ene-3,17 dione (115.0 Ci/mmol) and $17-\beta-2,4,6,7-\left[{ }^{3} \mathrm{H}\right]$-estradiol $(102.0 \mathrm{Ci} / \mathrm{m}$ mol) were provided by New England Nuclear Products (Boston, MA, USA).

\section{Experimental procedures}

Extraction of SMG fixed in situ for localisation of oestrogenic receptors by immunohistochemistry

Rats on oestrus day were anaesthetised under ether bell. The SMG and nearby ganglia were fixed in situ with Bouin solution for subsequent extraction and application of immunohistochemistry.

\section{Extraction of the SMG-ONP-ovary system}

Groups of six animals on oestrus day were used. The procedure was carried out between 1500 and $1600 \mathrm{~h}$ taking into account previous descriptions of the anatomical trajectory of this neural pathway as a guide (Lawrence \& Burden 1980, Klein \& Burden 1988a, 1988b, Vega Orozco et al. 2006).

The piece of tissue utilised in this work corresponds to the whole SMG where the principal neurons are located, whose axons constitute the ONP that reaches the ovary, without the presence of the coeliac ganglion (Vega Orozco et al. 2006).

The anatomical localisation of the SMG and coeliac ganglia (CG) is different, as well as the neuron type and size. The SMG was extracted from the area proximal to the CG, proximal to the renal artery and abdominal aorta artery. It is important to clarify immediately before and after incubation (120 min) that the presence of the SMG was confirmed in the system by the application of routine histological techniques. The presence of the ganglion was verified in the removed system before incubation in similar conditions to the systems that were going to be used later.

Rats were anaesthetised with ether under a bell, and the ex vivo system was immediately removed by dissection.

Each system consisted of the ovary, the fibres constituting the ONP, parallel to the ovarian artery, and the SMG, surrounded by some small ganglia.
The total surgical procedure was completed in 1-2 min. The strip of tissue was carefully dissected, avoiding contact between the surgical instruments, the nerve fibres and the ganglion to prevent spontaneous depolarisations of the nerves, which might have been caused by inappropriate contact.

The extracted systems were washed with incubation solution and immediately placed in a cuvette with two compartments. Each cuvette contained $2 \mathrm{ml}$ of work solution, Krebs-Ringer bicarbonate buffer, $\mathrm{pH} 7.4$, in the presence of dextrose $(0.1 \mathrm{mg} / \mathrm{ml})$ and BSA $(0.1 \mathrm{mg} / \mathrm{ml})$ as described in previous studies (Sosa et al. 2000, Vega Orozco et al. 2006).

The ganglion was placed in one compartment and the ovary in the other, both joined by the ONP, which was maintained humid with the work solution. The system was immediately preincubated in a metabolic bath at $37^{\circ} \mathrm{C}$ in a saturated $\mathrm{O}_{2} / \mathrm{CO}_{2}(95-5 \%)$ atmosphere for $15 \mathrm{~min}$ to achieve the stabilisation of the system as described in a previous study (Vega Orozco et al. 2006).

After $15 \mathrm{~min}$ of preincubation (time 0 of incubation), the Krebs-Ringer solution was changed in both compartments, and ascorbic acid $(0.1 \mathrm{mg} / \mathrm{ml}$ in Krebs-Ringer) was added as an antioxidant agent (Koh \& Hille 1997) in the ganglion compartment whereas the Krebs-Ringer solution was added in the ovary compartment. The $\mathrm{P}_{4}, \mathrm{~A}_{2}$ and nitrite values released under these conditions were considered as control values (control group).

The experimental groups proposed were a) SMG-ONPovary system with the addition of $E_{2}\left(10^{-6} \mathrm{~mol} / \mathrm{l}\right)$ in the ganglion compartment, b) SMG-ONP-ovary system with addition of $\operatorname{Txf}\left(10^{-6} \mathrm{~mol} / \mathrm{l}\right)$ in the ganglion compartment and c) SMG-ONP-ovary system with addition of Txf $\left(10^{-6} \mathrm{~mol} / \mathrm{l}\right)$ and $E_{2}\left(10^{-6} \mathrm{~mol} / \mathrm{l}\right) 5 \mathrm{~min}$ later in the ganglion compartment. Groups $b$ and $c$ were only used for $\mathrm{P}_{4}$ release determination and for evaluating whether Txf acts as an oestrogenic antagonist at ganglionic level. The control group was SMGONP-ovary system without treatment (control). The different substances were dissolved in equal concentration $\left(10^{-6} \mathrm{~mol} / \mathrm{l}\right)$ and volumes $(2 \mathrm{ml})$ of Krebs-Ringer buffer plus ascorbic acid.

For the system standardisation, the dose/response curve was obtained for this ex vivo system and at the working times used. The curve shows the highest $\mathrm{P}_{4}$ increase with the used dose $\left(10^{-6} \mathrm{~mol} / \mathrm{l}\right)$ compared with other doses used.

Liquid samples from the ovary compartment $(250 \mu \mathrm{l})$ were collected at 15, 30, 60 and $120 \mathrm{~min}$ and kept at $-20^{\circ} \mathrm{C}$ until the determination of $\mathrm{P}_{4}$ and $\mathrm{A}_{2}$ by RIA and NO using the Griess method.

The results were expressed as the nanogram of $\mathrm{P}_{4}$ and picogram of $\mathrm{A}_{2}$ per milligram of ovarian tissue per millilitre and nitrites as nanomol of nitrites per milligram of ovarian tissue per millilitre $(\mathrm{nmol} / \mathrm{mg}$ ovary/ml) all against the incubation time. The respective corrections were made in all cases considering the volume extracted in each tested period. When the system incubation was finished (120 min), the ovaries were kept at $-80{ }^{\circ} \mathrm{C}$ until determination of $3 \beta-\mathrm{HSD}$ and $20 \alpha-\mathrm{HSD}$ activities and gene expression.

\section{Immunohistochemistry}

After the experimental treatment, the SMGs were fixed in $4 \%$ paraformaldehyde, included in paraffin and sectioned at $5 \mu \mathrm{m}$. 
For immunohistochemistry, sections were deparaffinised, rehydrated and rinsed in distilled water. After antigen retrieval using microwave treatment at $160 \mathrm{~W}$ in $10 \mathrm{mM}$ sodium citrate, $\mathrm{pH}$ 6.0, for $30 \mathrm{~min}$, sections were washed in PBS and incubated for $20 \mathrm{~min}$ in $0.3 \%$ hydrogen peroxide in PBS to inhibit endogenous peroxidases. Then, sections were permeabilised by 30-min incubation in PBS containing $0.5 \%$ Triton X-100 and blocked in PBS containing 0.5\% Triton X-100 and 2\% BSA for $1 \mathrm{~h}$. Sections were incubated overnight at $4{ }^{\circ} \mathrm{C}$ with the appropriate primary antibody diluted in blocking solution. The primary antibodies used were as follows: a polyclonal rabbit anti-ER $\alpha$ (ER $\alpha, M C-20$; SC-542, Santa Cruz Biotechnology, Santa Cruz, CA, USA; 1:400) and a rabbit polyclonal anti-serum against ER $\beta$ (ER $\beta, \mathrm{H}-150$; SC-8974 Santa Cruz Biotechnology; 1:100). Subsequently, sections were rinsed in PBS, incubated with biotinylated secondary antibody (1:300 in blocking solution) for $1 \mathrm{~h}$, washed in PBS and incubated for $1 \mathrm{~h}$ with avidin-biotin complex (Vector Laboratories, Burlingame, CA, USA). After several washes in PBS, sections were exposed to a $0.02 \%$ 3,3'-diaminobenzidine (Sigma-Aldrich Co.) solution. The reaction was stopped in tap water and some sections were counterstained in haematoxylin (20 s), dehydrated in ethanol, cleared in xylene, coverslipped and examined on a Nikon photomicroscope. Each immunoreaction was performed on at least three slides from each set of ganglia. Sections of uterus and ovary were processed in parallel under identical conditions and used as positive controls; staining in these tissues showed strong, predominantly nuclear localisation with both antibodies. To confirm the specificity of the staining, selected sections were incubated without primary or secondary antibodies with positive and negative controls being included.

\section{Nitrite assay}

Levels of nitrite, a water-soluble metabolite of NO, were measured spectrophotometrically by the Griess method and were expressed in nanomole of nitrite per milligram of ovarian tissue per millilitre $(\mathrm{nmol} / \mathrm{mg}$ ovary per $\mathrm{ml}$; Egami \& Taniguchi 1974). The samples $(50 \mu \mathrm{l})$ were immediately mixed with Griess reagent (sulphanilamide with $\mathrm{N}$-(1-naphthyl) ethylenediamine/ $\mathrm{HCl}$ ). After $10 \mathrm{~min}$ of incubation at room temperature, it was read for absorbance at $540 \mathrm{~nm}$, and nanomoles of nitrite were determined using a standard curve. The assay sensitivity was $<2.5 \mathrm{nmol} / \mathrm{ml}$. The intra-assay coefficient of variation for all the assays was $<10.0 \%$.

\section{$P_{4}$ and $A_{2}$ assay}

Steroids were measured in duplicate by RIA. The anti-sera to $\mathrm{P}_{4}$ were kindly provided by Dr R Deis (Laboratorio de Reproducción y Lactancia, Mendoza, Argentina). $\mathrm{P}_{4}$ was measured in nanogram per milligram ovary per millilitre and assay sensitivity was $<5 \mathrm{ng} \mathrm{P}_{4} / \mathrm{ml}$. $\mathrm{A}_{2}$ was expressed as picogram per milligram of ovarian tissue per millilitre ( $\mathrm{pg} / \mathrm{ml}$ ovary per $\mathrm{ml}$ ), all against incubation time on the systems. The assay sensitivity was $<10 \mathrm{pg} \mathrm{A}_{2} / \mathrm{ml}$. The inter- and intra-assay coefficients of variation in all the assays were $<10.0 \%$. The result of each experiment is expressed with respect to the corresponding control group.

\section{Enzymatic activity}

The activities of $3 \beta-\mathrm{HSD}$ and $20 \alpha-\mathrm{HSD}$ were measured according to Kawano et al. (1988) with a slight modification. The ovary from each animal was homogenised in $0.7 \mathrm{ml}$ of $0.1 \mathrm{M}$ Tris- $\mathrm{HCl}, 1 \mathrm{mM}$ EDTA $(\mathrm{pH} 8)$ at $0{ }^{\circ} \mathrm{C}$ with a glass homogeniser. The homogenates were centrifuged at $105000 \mathrm{~g}$ for $60 \mathrm{~min}$. The supernatant fluids were used for the assay of $20 \alpha-\mathrm{HSD}$ activity. The precipitates were rehomogenised with $0.7 \mathrm{ml}$ of $0.25 \mathrm{M}$ sucrose and centrifuged at $800 \mathrm{~g}$ for $5 \mathrm{~min}$. The supernatants were used as the enzyme solution for the assay of $3 \beta-\mathrm{HSD}$ activity. The substrates for $3 \beta-\mathrm{HSD}$ and $20 \alpha-\mathrm{HSD}$ were pregnenolone $(5 \mu \mathrm{g})$ and $20 \alpha$-hydroxypregn-4-en-3-one (12.5 $\mu \mathrm{g})$ respectively. Both enzyme activities were assayed spectrophotometrically, depending on the increase in $\mathrm{NADH}$ or $\mathrm{NADPH}$ in $1 \mathrm{~min}$ at $37^{\circ} \mathrm{C}$, and the values were expressed as $\mathrm{mU} / \mathrm{mg}$ protein/min. The method of Lowry et al. (1951) was used for protein determination with BSA as the standard.

\section{RNA isolation and RT-PCR analysis}

Once the ovaries were defrosted, the total RNA was extracted using the TRIzol-reagent method (Invitrogen Life Technologies), following the manufacturer's instructions for the RNA extraction (Chomczynski 1993).

Two micrograms of total RNA were reverse transcribed using a Moloney murine leukaemia virus (MMLV) RT and random primers. First, a prereverse transcription (pre-RT) was carried out, using random primers, by incubating for $10 \mathrm{~min}$ at room temperature and then $45 \mathrm{~min}$ at $42{ }^{\circ} \mathrm{C}$. The buffer $\mathrm{RT}$, the enzyme MMLV-RT (Invitrogen Life Technologies) and a mixture of dNTPs were added to the total pre-RT product, and it was carried to a final volume of $50 \mu \mathrm{l}$. The mixture was incubated for $60 \mathrm{~min}$ at $42{ }^{\circ} \mathrm{C}$, then $15 \mathrm{~min}$ at $70{ }^{\circ} \mathrm{C}$ and finally the reverse transcriptase activity was inactivated by incubating the tubes in an ice bath.

For amplification of the RT products, the reaction mixture consisted of $10 \mu \mathrm{l}$ Go Taq Green reaction buffer, $0.2 \mathrm{mM}$ dNTPs, $0.5 \mu \mathrm{M}$ specific oligonucleotide primers and $1.25 \mathrm{U}$ Go Taq DNA polymerase (Promega, Inc.) in a final volume of $50 \mu \mathrm{l}$. Amplification was carried out for 30 cycles using $93{ }^{\circ} \mathrm{C}$ for denaturation $(1 \mathrm{~min}), 59{ }^{\circ} \mathrm{C}$ for annealing $(1 \mathrm{~min})$ and $72{ }^{\circ} \mathrm{C}$ for extension $(15 \mathrm{~min})$ in an Eppendorf thermal cycler.

Specific primers for $3 \beta$-HSD were $5^{\prime}$-CTGCCTGGTGACAGGAGCAGG-3' and $5^{\prime}$-GCCAGCACTGCCTTCTCGGCC- $3^{\prime}$ and for $20 \alpha$-HSD were $5^{\prime}$-TTCGAGCAGAACTCATGGCTA- $3^{\prime}$ and 5'-CAACCAGGTAGAATGCCATCT-3'. Each reaction also included primers (5'-CAAGACTGAGTGGCTGGATGG-3' and $5^{\prime}$-ACTTGAAGGGGAATGAGGAAAA- $3^{\prime}$ ) to amplify protein cyclophilin $A$ as an internal control. The predicted sizes of the PCR-amplified products were $489 \mathrm{bp}$ for $3 \beta$-HSD, $440 \mathrm{pb}$ for $20 \alpha-H S D$ and 293 pb for cyclophilin A. Reaction products were electrophoresed on $1.5 \%$ agarose gels, visualised with ethidium bromide $(5.5 \mathrm{mg} / \mathrm{ml})$ and examined by u.v. transillumination. Band intensities of RT-PCR products were quantified using ImageJ (NIH, Bethesda, MA, USA; http://rsb.info.nih.gov/ $\mathrm{ij} /$ ) and expressed as arbitrary units. 


\section{Statistical analysis}

All data are presented as the mean \pm s.E.M. in each group of six rats. Differences between two groups were analysed with the Student's $t$-test. ANOVA I followed by the Tukey's test was used for between-group comparison. A value of $P<0.05$ was considered statistically significant (Snedecor \& Cochram 1976).

\section{Declaration of interest}

The authors declare that there is no conflict of interest that could be perceived as prejudicing the impartiality of the research reported.

\section{Funding}

This work was supported by Grant 9302 from Universidad Nacional de San Luis, Argentina.

\section{Acknowledgements}

We thank Susana Rezzano for English language assistance. We also acknowledge Carlos Pellarin for his technical assistance. This work is part of the doctoral thesis of biochemist Adriana Vega Orozco, funded by Secretaria de Ciencia y Técnica, Universidad Nacional de San Luis.

\section{References}

Aguado LI \& Ojeda SR 1984 Prepubertal ovarian function is finely regulated by direct adrenergic influences: role of noradrenergic innervation. Endocrinology 114 1845-1853. (doi:10.1210/endo-114-5-1845)

Anesetti G, Lombide P \& Chavez-Genaro R 2009 Prepubertal exposure modifies neurotrophin receptor expression in celiac neurons and alters ovarian innervation. Autonomic Neuroscience 1-2 35-43. (doi:10.1016/ j.autneu.2008.10.021)

Baljet B \& Drukker J 1979 The extrinsic innervation of the abdominal organs in the female rat. Acta Anatomica 104 243-267. (doi:10.1159/ 000145073)

Barria A, Leyton V, Ojeda SR \& Lara HE 1993 Ovarian steroidal response to gonadotropins and beta-adrenergic stimulation is enhanced in polycystic ovary syndrome: role of sympathetic innervation. Endocrinology 133 2696-2703. (doi:10.1210/en.133.6.2696)

Berman JR, McCarthy MM \& Kyprianou N 1998 Effect of estrogen withdrawal on nitric oxide synthase expression and apoptosis in the rat vagina. Urology 51 650-656. (doi:10.1016/S0090-4295(97)00683-3)

Blaustein JD 1992 Cytoplasmic estrogen receptors in rat brain immunocytochemical evidence using three antibodies with distinct epitopes. Endocrinology 131 1336-1342. (doi:10.1210/en.131.3.1336)

Cardinali DP, Vacas MI, Gejman PV, Pisarev MA, Barontin M \& Boado RJ 1983 The sympathetic superior cervical ganglia as "little neuroendocrine brains". Acta Physiologica Latino Americana 33 205-221.

Casais M, Delgado SM, Sosa ZY, Telleria CM \& Rastrilla AM 2006 The celiac ganglion modulates $\mathrm{LH}$-induced inhibition of androstenedione release in late pregnant rat ovaries. Reproductive Biology and Endocrinology 4 66-72. (doi:10.1186/1477-7827-4-66)

Chomczynski P 1993 A reagent for the single-step simultaneous isolation of RNA, DNA and proteins from cell and tissue samples. Biotechniques 15 532-534, 536-537.

Dalsgaard CJ, Vincent SR, Hökfelt T, Lundberg JM, Dahlström A, Schultzberg M, Dockray GJ \& Cuello AC 1982 Coexistence of cholecystokinin- and substance P-like peptides in neurons of the dorsal root ganglia of the rat. Neuroscience Letters 33 159-163. (doi:10.1016/ 0304-3940(82)90244-0)
Deecher DC, Swiggard P, Frail DE \& O'Connor LT 2003 Characterization of a membrane-associated estrogen receptor in a rat hypothalamic cell line (D12). Endocrine 22 211-223. (doi:10.1385/ENDO:22:3:211)

Delgado SM, Sosa Z, Dominguez NS, Casais M, Aguado L \& Rastrilla AM 2004 Effect of the relation between neural cholinergic action and nitric oxide on ovarian steroidogenesis in prepubertal rats. Journal of Steroid Biochemistry and Molecular Biology 91 139-145. (doi:10.1016/j.jsbmb. 2004.04.004)

Dong YL, Gangula PR, Fang L \& Yallampalli C 1999 Nitric oxide reverses prostaglandin-induced inhibition in ovarian progesterone secretion in rats. Human Reproduction 14 27-32. (doi:10.1093/humrep/14.1.27)

Doolan CM \& Harvey BJA 2003 Galphas protein-coupled membrane receptor, distinct from the classical oestrogen receptor, transduces rapid effects of oestradiol on $\left[\mathrm{Ca}^{2+}\right]_{i}$ in female rat distal colon. Molecular and Cellular Endocrinology 199 87-103. (doi:10.1016/S0303-7207(02) 00303-9)

Dun SL, Brailoiu GC, Gao X, Brailoiu E, Arterburn JB, Prossnitz ER, Oprea TI \& Dun NJ 2009 Expression of estrogen receptor GPR30 in the rat spinal cord and in autonomic and sensory ganglia. Journal of Neuroscience Research 87 1610-1619. (doi:10.1002/jnr.21980)

Dunnam RC, Hill MJ, Lawson M \& Dunbar JC 1999 Ovarian hormone secretory response to gonadotropins and nitric oxide following chronic oxide deficiency in the rat. Biology of Reproduction $60959-963$. (doi:10.1095/biolreprod60.4.959)

Egami F \& Taniguchi S 1974 Nitrate. In, Methods of Enzymatic Analysis, 2nd edn, pp 2260-2265. Ed HU Bergmeyr. New York, NY, USA: Academic Press.

Eisenhofer G, Kopin IJ \& Goldstein DS 2004 Catecholamine metabolism: a contemporary view with implications for physiology and medicine. Pharmacological Reviews 56 331-349. (doi:10.1124/pr.56.3.1)

Eränkö O 1978 Small intensely fluorescent (SIF) cells and nervous transmission in sympathetic ganglia. Annual Review of Pharmacology and Toxicology 18 417-430. (doi:10.1146/annurev.pa.18.040178.002221)

Fridén B, Runesson E, Hahlin M \& Brannstrom M 2000 Evidence for nitric oxide acting as a luteolytic factor in the human corpus luteum. Molecular Human Reproduction 6 397-405. (doi:10.1093/molehr/6.5.397)

Garcia-Rudaz C, Armando I, Levin G, Escobar ME \& Barontini M 1998 Peripheral catecholamine alterations in adolescents with polycystic ovary syndrome. Clinical Endocrinology 49 221-228. (doi:10.1046/j. 1365-2265.1998.00511.x)

Garraza MH, Aguado LI \& De Bortoli MA 2004 In vitro effect of neuropeptides on ovary or celiac ganglion affects the release of progesterone from ovary in the rat. Medical Science Monitor 10 440-446.

Heldring N, Pike A, Andersson S, Matthews J, Cheng G, Hartman J, Tujague M, Ström A, Treuter E, Warner M et al. 2007 Estrogen receptors: how do they signal and what are their targets. Physiological Reviews 87 905-931. (doi:10.1152/physrev.00026.2006)

Hsueh AJ, Adashi EY, Jones PBC \& Welsh TH Jr 1984 Hormonal regulation of the differentiation of cultured ovarian granulosa cells. Endocrine Reviews 5 76-127. (doi:10.1210/edrv-5-1-76)

Kawano T, Okamura H, Tajima C, Fukuma K \& Katabuchi H 1988 Effect of RU 486 on luteal function in the early pregnant rat. Journal of Reproduction and Fertility 83 279-285. (doi:10.1530/jrf.0.0830279)

Klein CM \& Burden HW 1988a Anatomical localization of afferent and postganglionic sympathetic neurons innervating the rat ovary. Neuroscience Letters 85 217-222. (doi:10.1016/0304-3940(88)90354-0)

Klein CM \& Burden HW $1988 b$ Substance P and vasoactive intestinal polypeptide (VIP) inmunoreactive nerve fibers in relation to ovarian postganglionic perikarya in para- and prevertebral ganglia: evidence from combined retrograde tracing and immunocytochemistry. Cell and Tissue Research 252 403-410. (doi:10.1007/BF00214383)

Koh DS \& Hille B 1997 Modulation by neurotransmitters of catecholamine secretion from sympathetic ganglion neurons detected by amperometry. PNAS 94 1506-1511. (doi:10.1073/pnas.94.4.1506)

Koszykowska M, Calka J, Szwajca P \& Jana B 2011 Long-term estradiol-17 $\beta$ administration decreases the number of neurons in the caudal mesenteric ganglion innervating the ovary in sexually mature gilts. Journal of Reproduction and Development 57 62-71. (doi:10.1262/jrd.10-061S)

Kotwica GJ, Rekawiecki R \& Duras M 2004 Stimulatory influence of progesterone on its own synthesis in bovine corpus luteum. Bulletin of the Veterinary Institute in Pulawy 48 139-145. 
Kuiper GG, Carlsson B, Grandien K, Enmark E, Häggblad J, Nilsson S \& Gustafsson JA 1997 Comparison of the ligand binding specificity and transcript tissue distribution of estrogen receptors alpha and beta. Endocrinology 138 863-870. (doi:10.1210/en.138.3.863)

Kuiper GG, Van den Bemd GJ \& Van Leeuwen JP 1999 Estrogen receptor and the SERM concept. Journal of Endocrinological Investigation 22 594-603.

Lara HE, Dissen GA, Leyton V, Paredes A, Fuenzalida H, Fiedler JL \& Ojeda SR 2000 An increased intraovarian synthesis of nerve growth factor and its low affinity receptor is a principal component of steroidinduced polycystic ovary in the rat. Endocrinology 141 1059-1072. (doi:10.1210/en.141.3.1059)

Lara $\mathrm{HE}$, Dorfman M, Venegas M, Luza SM, Luna SL, Mayerhofer A, Guimaraes MA, Rosa ESAA \& Ramirez VD 2002 Changes in sympathetic nerve activity of the mammalian ovary during a normal estrous cycle and in polycystic ovary syndrome: studies on norepinephrine release. Microscopic Research and Technique 59 495-502. (doi:10.1002/jemt. 10229)

Lars-Gösta E, Holmberg K, Emson P, Schemmann M \& Hokfelt T 1997 Nitric oxide synthase, choline acetyltransferase, catecholamine enzymes and neuropeptides and their colocalization in the anterior pelvic ganglion and hypogastric nerve of the male guinea pig. Anatomical Record 35 68-76.

Lawrence IE Jr \& Burden HW 1980 The origin of the extrinsic adrenergic innervation to the ovary. Anatomical Record 196 51-59. (doi:10.1002/ar. 1091960106)

Levin ER 2001 Cell localization, physiology, and nongenomic actions of estrogen receptors. Journal of Applied Physiology 91 1860-1867.

Lowry OH, Rosebrough HJ, Farr AL \& Randall RJ 1951 Protein measurement with the folin phenol reagent. Journal of Biological Chemistry 193 265-275.

Mannisto PT \& Kaakkola S 1999 Catechol-O-methyltransferase (COMT): biochemistry, molecular biology, pharmacology, and clinical efficacy of the new selective COMT inhibitors. Pharmacological Reviews $\mathbf{5 1}$ 593-628.

Mao J, Duan RW, Zhong L, Gibori G \& Azhar S 1997 Expression, purification and characterization of the rat luteal 20 $\alpha$-hydroxysteroid dehydrogenase. Endocrinology 1 182-190. (doi:10.1210/en.138.1.182)

Miszkiel G, Skarzynski D, Bogacki M \& Kotwica J 1999 Concentrations of catecholamines, ascorbic acid, progesterone and oxytocin in the corpora lutea of cyclic and pregnant cattle. Reproduction, Nutrition, Development 39 509-516. (doi:10.1051/rnd:19990410)

Miyamoto A, Brückmann A, von Lützow H \& Schams D 1993 Multiple effects of neuropeptide $Y$, substance $P$ and vasoactive intestinal polypeptide on progesterone and oxytocin release from bovine corpus luteum in vitro. Journal of Endocrinology 138 451-458. (doi:10.1677/ joe.0.1380451)

Mosselman S, Polman J \& Dijkema R 1996 ERbeta: identification and characterization of a novel human estrogen receptor. FEBS Letters 392 49-53. (doi:10.1016/0014-5793(96)00782-X)

Motta AB, Estevez A, Tognetti T, Gimeno MA \& Franchi AM 2001 Dual effects of nitric oxide in functional and regressing rat corpus luteum. Molecular Human Reproduction 7 43-47. (doi:10.1093/molehr/7.1.43)

Navarro Despaigne D 2001 Moduladores selectivos del receptor estrógenico. Su utilidad en la mujer posmenopáusica. Rev. Cubana. Endocrinology 12 124-127.

Olson L, Jones BCh \& Jablonka-Shariff A 1996 Nitric oxide decreases estradiol synthesis of rats luteinized ovarian cells: possible role for nitric oxide in functional luteal regression. Endocrinology 137 3531-3536. (doi:10.1210/en.137.8.3531)

Paech K, Webb P, Kuiper GG, Nilsson S, Gustafsson J, Kushner PJ \& Scanlan TS 1997 Differential ligand activation of estrogen receptors ERalpha and ERbeta at AP1 sites. Science 277 1508-1510. (doi:10.1126/ science.277.5331.1508)

Paige LA, Christensen DJ, Grøn H, Norris JD, Gottlin EB, Padilla KM, Chang CY, Ballas LM, Hamilton PT, McDonnell DP et al. 1999 Estrogen receptor (ER) modulators each induce distinct conformational changes in ER alpha and ER beta. PNAS 96 3999-4004. (doi:10.1073/pnas.96.7. 3999)

Papka RE, Estorey-Workley M, Shughrue PJ, Merchenthaler I, Kollins JJ, Usip S, Saunders PT \& Shupnik M 2001 Estrogen receptor-alpha and beta-immunoreactivity and mRNA in neurons of sensory and autonomic ganglia and spinal cord. Cell and Tissue Research 2 193-214. (doi:10. 1007/s004410100363)

Poole T 1999 UFAW hand book of the care and management of Laboratory animals, vol 2, 7th edn. Oxford, UK: Blackwell Publishing.

Prud'Homme MJ, Houdeau E, Serghini R, Tillet Y, Schemann M \& Rousseau JP 1999 Small intensely fluorescent cells of the rat paracervical ganglion synthesize adrenaline, receive afferent innervation from postganglionic cholinergic neurones, and contain muscarinic receptors. Brain Research 821 141-149. (doi:10.1016/S0006-8993(99)01094-X)

Quinson N, Robbins HL, Clark MJ \& Furness JB 2001 Locations and innervation of cell bodies of sympathetic neurons projecting to the gastrointestinal tract in the rat. Archives of Histology and Cytology 64 281-294. (doi:10.1679/aohc.64.281)

Razandi M, Pedram A, Merchenthaler I, Greene GL \& Levin ER 2004 Plasma membrane estrogen receptors exist and functions as dimers. Molecular Endocrinology 18 2854-2865. (doi:10.1210/me.20040115)

Rekawiecki R, Nowik M \& Kotwica J 2005 Stimulatory effect of LH, PGE $E_{2}$ and progesterone on StAR protein, cytochrome P450 cholesterol side chain cleavage and $3 \beta$-hydroxysteroiddehydrogenase gene expression in bovine luteal cells. Prostaglandins \& Other Lipid Mediators 78 169-184. (doi:10.1016/j.prostaglandins.2005.06.009)

Rekawiecki R, Kowalik MK, Slonina D \& Kotwica J 2008 Regulation of progesterone synthesis and action in bovine corpus luteum. Journal of Physiology and Pharmacology 59 75-89.

Rosa ESA, Guimaraes MA, Padmanabhan V \& Lara HE 2003 Prepubertal administration of estradiol valerate disrupts cyclicity and leads to cystic ovarian morphology during adult life in the rat: role of sympathetic innervation. Endocrinology 144 4289-4297. (doi:10.1210/en.20030146)

Shinohara Y, Matsumoto A \& Mori T 1998 Effects of prenatal exposure to diethylstilbestrol on the sympathetic nervous system in the rat ovary. Neuroscience Letters 255 123-126. (doi:10.1016/S03043940(98)00681-8)

Shinohara Y, Matsumoto A, Hayashi S \& Mori T 2000 Prenatal exposure to diethylstilbestrol decreases the number of estrogen receptor alphacontaining neurons innervating the ovary in rat celiac ganglion. Neuroscience 101 779-783. (doi:10.1016/S0306-4522(00)00395-X)

Singh M, Sétálo G, Guan X, Wuaren M \& Toran-Allerand CD 1999 Estrogen-induced activation of mitogen-activated proteinkinase in cerebral cortical explants: convergence of estrogen and neurotrophin signalling pathways. Journal of Neuroscience 4 1179-1188.

Snedecor WG \& Cochram WG 1976 Statistical Methods, Ames, lowa: The lowa State University Press.

Snyder GD, Holmes RW, Bates JN \& Van Voorhis BJ 1996 Nitric oxide inhibits aromatase activity: mechanisms of action. Journal of Steroid Biochemistry and Molecular Biology 58 63-69. (doi:10.1016/09600760(96)00008-8)

Sohrabji F, Greene LA, Miranda RC \& Toran-Allerand CD 1994a Reciprocal regulation of estrogen and NGF receptors by their ligands in PC12 cells. Journal of Neurobiology 25 974-988. (doi:10.1002/neu. 480250807)

Sohrabji F, Miranda RC \& Toran-Allerand CD 1994b Estrogen differentially regulates estrogen and nerve growth factor receptor mRNAs in adult sensory neurons. Journal of Neuroscience 14 459-471.

Song RX \& Santen RJ 2006 Membrane initiated estrogen signaling in breast cancer. Biology of Reproduction 75 9-16. (doi:10.1095/biolreprod.105. 050070)

Song RX, Zhang Z \& Santen RJ 2005 Estrogen rapid action via protein complex formation involving ERalpha and Src. Trends in Endocrinology and Metabolism 16 347-353. (doi:10.1016/j.tem.2005.06.010)

Sosa ZY, Casais M, Rastrilla AM \& Aguado LI 2000 Adrenergic influences on coeliac ganglion affect the release of progesterone from cycling ovaries. Characterisation of an in vitro system. Journal of Endocrinology 166 307-318. (doi:10.1677/joe.0.1660307)

Sosa Z, Delgado SM, Casais M, Aguado L \& Rastrilla AM 2004 Release of ovarian progesterone during the rat oestrous cycle by ganglionic cholinergic influence. The role of norepinephrine. Journal of Steroid Biochemistry and Molecular Biology 91 179-184. (doi:10.1016/j.jsbmb. 2004.03.119) 
Stefano G, Cadet P, Mantione K, Cho J, Jones D \& Zhu W 2003 Estrogen signalling at the cell surface coupled to nitric oxide release in Mytilus edilus nervous system. Endocrinology 144 1234-1240. (doi:10.1210/en. 2002-220967)

Stocco CO \& Deis RP 1996 Luteolytic effect of LH: inhibition of 3ßhydroxysteroid dehydrogenase and stimulation of $20 \alpha$-hydroxysteroid dehydrogenase luteal activities in late pregnant rats. Journal of Endocrinology 150 423-429. (doi:10.1677/joe.0.1500423)

Sun L, Wen L, Shao X, Qian H, Jin Y, Liu W \& Fu Z 2010 Screening of chemicals with anti-estrogenic activity using in vitro and in vivo vitellogenin induction responses in zebrafish (Danio rerio). Chemosphere 78 793-799. (doi:10.1016/j.chemosphere.2009.12.020)

Tellería CM, Stocco CO, Stati AO, Rastrilla AM, Carrizo DG, Aguado LI \& Deis RP 1995 Dual regulation of luteal progesterone production by androstenedione during spontaneous and RU486-induced luteolysis in pregnant rats. Journal of Steroid Biochemistry and Molecular Biology 55 385-393. (doi:10.1016/0960-0760(95)00190-5)

Vega Orozco A, Sosa Z, Fillipa V, Mohamed F \& Rastrilla AM 2006 The cholinergic influence on the mesenteric ganglion affects the liberation of ovarian steroids and nitric oxide in oestrus day rats: characterization of an ex vivo system. Journal of Endocrinology 191 587-598. (doi:10.1677/ joe.1.06859)

Vega Orozco A, Sosa Z, Delgado S, Casais M \& Rastrilla AM 2010 Involvement of ganglionic cholinergic receptors on the steroidogenesis in the luteal phase in rat. Journal of Steroid Biochemistry and Molecular Biology 120 45-52. (doi:10.1016/j.jsbmb.2010.03.040)

Wang Z, Zhang X, Shen P, Loggie BW, Chang Y \& Deuel TF 2005 Identification, cloning, expression of human estrogen receptor-alpha36 a novel variant of human estrogen receptor-alpha66. Biochemical and Biophysical Research Communications 366 1023-1027. (doi:10.1016/j. bbrc.2005.08.226)

Warner M \& Gustafsson JA 2006 Nongenomic effects of estrogen: why all the uncertainty? Steroids 71 91-96. (doi:10.1016/j.steroids.2005.09.001)
Webb P, Lopez GN, Uht RM \& Kushner PJ 1995 Tamoxifen activation of the estrogen receptor/AP-1 pathway: potential origin for the cell-specific estrogen-like effects of antiestrogens. Molecular Endocrinology 9 443-456. (doi:10.1210/me.9.4.443)

Weihua Z, Andersson S, Cheng G, Simpson ER, Warner M \& Gustafsson JA 2003 Update on estrogen signaling. FEBS Letters 546 17-24. (doi:10. 1016/S0014-5793(03)00436-8)

Yamamoto R, Wada A, Asada Y, Niina H \& Sumiyoshi A 1993 N omeganitro-larginine, an inhibitor of nitric oxide synthesis, decreases noradrenaline outflowin rat isolated perfused mesenteric vasculature. Naunyn-Schmiedeberg's Archives of Pharmacology 347 238-240. (doi:10.1007/BF00169274)

Zou A, Marschke KB, Arnold KE, Berger EM, Fitzgerald P, Mais DE \& Allegretto EA 1999 Estrogen receptor beta activates the human retinoic acid receptor alpha-1 promoter in response to tamoxifen and other estrogen receptor antagonists, but not in response to estrogen. Molecular Endocrinology 13 418-430. (doi:10.1210/me.13.3.418)

Zoubina EV \& Smith PG 2002 Distributions of estrogen receptors alpha and beta in simpathetic neurons of female rats: enriched expression by uterine innervation. Journal of Urology 169 382-385. (doi:10.1016/ S0022-5347(05)64132-8)

Zoubina EV \& Smith PG 2003 Expression of oestrogen receptors alpha and beta by sympathetic ganglion neurons projecting to the proximal urethra of female rats. Journal of Urology $1382-385$.

Received 10 March 2011

First decision 7 April 2011

Revised manuscript received 6 November 2011

Accepted 11 November 2011 